\title{
Biosynthesis and Characterization of Silver Nanoparticles using Catharanthus roseus Leaf Extract and its Proliferative Effects on Cancer Cell Lines
}

Ghozali SZ', Vuanghao $L^{2}$ and Ahmad $\mathrm{NH}^{1 *}$

${ }^{1}$ Oncological and Radiological Sciences Cluster, Advanced Medical and Dental Institute, USM Bertam, 13200 Kepala Batas, Penang, Malaysia

${ }^{2}$ Integrative Medicine Cluster, Advanced Medical and Dental Institute, USM Bertam, 13200 Kepala Batas, Penang, Malaysia

\begin{abstract}
Green synthesis is one of the most rapid, reliable, and best routes for the synthesis of silver nanoparticles (AgNPs). Previous studies demonstrated that active compounds in Catharanthus roseus were responsible for bioreduction during the synthesis of spherical AgNPs. In the present study, synthesis of AgNPs using C. roseus aqueous extract was optimized. To prepare the extract, dried C. roseus leaves were boiled at $100^{\circ} \mathrm{C}$ for $5 \mathrm{~min}$ or soaked in a water bath at $40^{\circ} \mathrm{C}$ for $24 \mathrm{~h}$. The extracts at concentrations of $10 \%$ and $20 \%$ were mixed with $\mathrm{AgNO}_{3}$ solutions of 1 and $5 \mathrm{mM}$. The resulting AgNPs were characterized by ultraviolet-visible (UV-Vis), X-ray diffraction (XRD), and transmission electron microscope (TEM). Cell proliferation of Jurkat (human acute T-cell leukemia) and HT-29 (human colorectal adenocarcinoma) cell lines in solutions containing synthesized AgNPs or $C$. roseus aqueous extract was measured by the MTS [3-(4,5-dimethylthiazol-2yl)-5-(3-carbonxymethoxyphenyl)-2-(4-sulfophenyl)-2H-tetrazolium/phenazine metho sulfate] assay using the double dilution approach (concentrations ranging from 3.91 to $1000 \mu \mathrm{g} / \mathrm{ml}$ ). UV-Vis spectra analysis indicated that the AgNPs at $5 \mathrm{mM}$ $\mathrm{AgNO}_{3}+10 \%$ extract produced the highest surface Plasmon resonance peak at approximately $500 \mathrm{~nm}$. The XRD analysis confirmed the presence of AgNPs with a face-centered cubic structure. TEM analysis showed that the AgNPs ranged in size from 20 to $50 \mathrm{~nm}$ with spherical shapes. Based on the MTS assay, the $\mathrm{IC}_{50}$ values of AgNPs ranged from 13.68 to 46.88 $\mu \mathrm{g} / \mathrm{ml}$ for both cancer cell lines, whereas the IC50 values of $C$. roseus aqueous extract ranged from 62.50 to $312.50 \mu \mathrm{g} / \mathrm{ml}$ for the Jurkat cell line and no IC50 values for HT-29 cell lines. Further studies should be conducted to validate the potential application of AgNPs as anti-cancer agents.
\end{abstract}

Keywords: C. roseus; Silver nanoparticles; Characterization; Anticancer

\section{Introduction}

Nanotechnology is an emerging field of nanoscience that is expected to be the starting point of many technological developments in the twenty-first century. The application of nanoscale materials and structures is gaining more and more attention due to their wide applicability, especially in biomedical fields (e.g., in the diagnosis and treatment of human cancers) [1]. The special characteristics of nanomaterials and their biologic effects suggest that nanoparticles may become potential alternative treatments of disease [2]. Gold, platinum, and silver nanoparticles are among the common types of nanoparticles that have been used widely in products that directly come in contact with the human body, including soaps, shampoos, shoes, detergent, tooth paste, cosmetic products, and medical and pharmaceutical devices [3]. Silver gained popularity when researchers found they could produce it at the nanoscale level. Ultrafine particles of metallic silver at the nanometer $(\mathrm{nm})$ scale were found to exhibited distinctive morphologies and characteristics [2]. Traditional methods of synthesizing nanoparticles include radiation, chemical or photochemical methods, electrochemical techniques, and Languir-Blodgett approaches [4]. However, these methods are extremely expensive and time consuming and can be dangerous to human health and the environment because of the application of hazardous substances [5]. Therefore, there is a growing need to develop cost-effective and environmentally friendly approaches for rapid synthesis of nanoparticles.

Biological approaches to the synthesis of metal nanoparticles using microorganisms and plant extracts have been suggested as valuable alternatives to chemical synthesis and physical methods [6,7]. Kotakadi [4] have described the use of natural materials such as plants, bacteria, fungi, yeast, and honey for synthesizing gold and silver nanoparticles. For example, Saifuddin [8] studied the applicability of bacteria Bacillus cereus and Mukherjee [9] on fungal species Trichoderma asperellum, for synthesizing nanoparticles.

The rate of synthesis of nanoparticles by plant extracts is higher than that of chemical methods and green synthesis by microorganisms [10]. In addition, the use of plant materials for the synthesis of nanoparticles does not require elaborate processes such as intracellular synthesis and multiple purification steps or the maintenance of microbial cell cultures [3]. Moreover, the use of plants for synthesis of nanoparticles is rapid, low cost, eco-friendly, and a single-step process [11]. Many previous studies reported the biosynthesis of silver nanoparticles (AgNPs) using extracts of leaves of various plants, including Pterocarpus santalinus [1], Moringa oleifera [5], Duranta repens [10], Oleo europaea [12], Loquat leaf extract [13], Annona squamosa [14], Rhinacanthus nasutus [15] and Catharanthus roseus [16]. Catharanthus roseus is an erect procumbent herb or undershrub containing latex that grows up to $1 \mathrm{~m}$ tall in subtropical areas [3]. This perennial herb is grown commercially for medicinal uses in India, Australia, Africa, and Southern Europe. It

*Corresponding authors: Ahmad $\mathrm{NH}$, Oncological and Radiological Sciences Cluster, Advanced Medical and Dental Institute, USM Bertam, 13200 Kepala Batas, Penang, Malaysia, Tel : +604-5622530; E-mail: hazwani_ahmad@amdi.usm.edu.my

Received May 19, 2015; Accepted June 12, 2015; Published June 22, 2015

Citation: Ghozali SZ, Vuanghao L, Ahmad NH (2015) Biosynthesis and Characterization of Silver Nanoparticles Using Catharanthus roseus Leaf Extract and its Proliferative Effects on Cancer Cell Lines. J Nanomed Nanotechnol 6: 305. doi:10.4172/2157-7439.1000305

Copyright: (c) 2015 Ghozali SZ, et al. This is an open-access article distributed under the terms of the Creative Commons Attribution License, which permits unrestricted use, distribution, and reproduction in any medium, provided the original author and source are credited. 
Citation: Ghozali SZ, Vuanghao L, Ahmad NH (2015) Biosynthesis and Characterization of Silver Nanoparticles using Catharanthus roseus Leaf Extract and its Proliferative Effects on Cancer Cell Lines. J Nanomed Nanotechnol 6: 305. doi:10.4172/2157-7439.1000305

contains alkaloids, mainly of the indole type. The root extract (alkaloid alstonine) is used to reduce hypertension, and reserpine, ajamalicine, and serpentine are alkaloids with antiplasmodic and hypotensive properties [17]. C. roseus also has antibacterial, anti-inflammatory, antidiuretic, cytotoxic, antifertility, hyperglycemic, antifungal, anti-malarial, and antivirus effects [16]. The alkaloids vinblastine and vincristine in C. roseus has been used as anti-cancer drugs in the treatment of different types of cancers, such as lymphomas, Hodgkin's lymphoma, breast cancer, acute lymphocytic leukemia, soft tissue sarcomas, multiple myeloma, and neuroblastoma [4]. Kotakadi [4] and Ponarulselvam et al. [17] successfully synthesized AgNPs from C. roseus leaf extract and its antimicrobial activity was tested. However, in the present study, the ability of extracts made from the dried leaves of $C$. roseus to synthesize AgNPs was evaluated, followed by a preliminary study of anticancer activity of these nanoparticles on selected cancer cell lines.

\section{Materials and Methods}

\section{Plant materials}

C. roseus plants were collected from Teluk Air Tawar, Butterworth, Penang. The plants were sent to the Herbarium Unit, School of Biological Sciences, and Universiti Sains Malaysia (USM) for identification. The voucher material was deposited at the same herbarium with reference number 10933.

\section{Preparation of $C$. roseus aqueous extract}

Two methods were used to prepare $C$. roseus aqueous extracts. Fresh leaves were washed and then dried in $40^{\circ} \mathrm{C}$ oven before being ground into powder form. Fifty grams of dried leaf powder were dissolved in $1000 \mathrm{~mL}$ distilled water for use in each method. Method 1 was performed according to Ahmad [18]. The mixture was incubated in a water bath shaker at $40^{\circ} \mathrm{C}$ for $24 \mathrm{~h}$. Method 2 was performed according to Gopinath [1], with slight modification. The mixture was boiled at $100^{\circ} \mathrm{C}$ on a hot plate for $5 \mathrm{~min}$. Following incubation for either $24 \mathrm{~h}$ or $5 \mathrm{~min}$, the extracts were centrifuged at $2000 \mathrm{rpm}$ for $15 \mathrm{~min}$ and filtered using Whatman filter paper No. 1 (Sartourie, Germany) to remove debris before being freeze dried.

\section{Synthesis of silver nanoparticles}

Four concentrations of C. roseus -AgNP solutions were prepared (Table 1). Different concentrations of $C$. roseus aqueous extracts and $\mathrm{AgNO}_{3}$ solutions were prepared by dissolution in distilled water. Five $\mathrm{ml}$ of $C$. roseus aqueous extract (w/v) was dissolved in $45 \mathrm{~mL}$ of $\mathrm{AgNO}_{3}$ solution (w/v) in a Scott Duran bottle and left at room temperature for $24 \mathrm{~h}$. A brown-yellow solution was formed, which indicated the presence of AgNPs (Figure 1). The solution was then centrifuged at $6000 \mathrm{rpm}$ for $15 \mathrm{~min}$. The supernatant was discarded and washed twice with distilled water. The pellet was dried in an oven at $40^{\circ} \mathrm{C}$ for $48 \mathrm{~h}$.

\section{Ultraviolet-Visible (UV-Vis) spectra analysis of silver nanoparticles}

Four concentrations of C. roseus-AgNP solutions were

\begin{tabular}{|c|c|}
\hline $\begin{array}{c}\text { Concentration of } \boldsymbol{C} \text {. roseus aqueous } \\
\text { extract (w/v) }\end{array}$ & Concentration of $\mathbf{A g N O}_{3(\mathbf{w} / \mathbf{v})}$ \\
\hline $10 \%$ & $1 \mathrm{mM}$ \\
\hline $10 \%$ & $5 \mathrm{mM}$ \\
\hline $20 \%$ & $1 \mathrm{mM}$ \\
\hline $20 \%$ & $5 \mathrm{mM}$ \\
\hline
\end{tabular}

Table 1: Concentrations of $C$. roseus aqueous extracts (w/v) and $\mathrm{AgNO}_{3}$ solutions $(w / v)$.
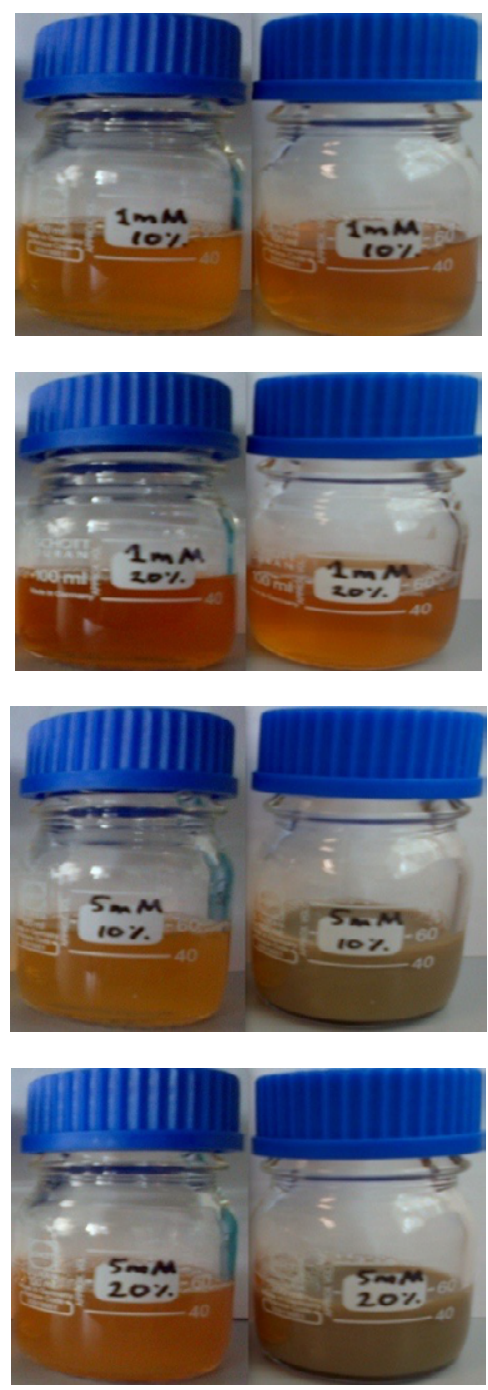

Figure 1: Color changes at $24 \mathrm{~h}$ of incubation after the addition of $10 \%(\mathrm{w} / \mathrm{v})$ and $20 \%(\mathrm{w} / \mathrm{v})$ of $C$. roseus aqueous extract to $1 \mathrm{mM}$ and $5 \mathrm{mM} \mathrm{AgNO}_{3}$ solution.

characterized using UV-Vis spectroscopy (UV-1650, Shimadzu, Japan) after incubation for $0,2,4,22,24$, and $48 \mathrm{~h}$. The bioreduction of the silver ions was monitored by measuring the absorbance of $1 \mathrm{ml}$ aliquots of the reaction mixture in a wavelength range between 400 and $600 \mathrm{~nm}$ with $1 \mathrm{~nm}$ resolution.

\section{$\mathrm{X}$-ray diffraction (XRD) analysis}

One gram of synthesized C. roseus-AgNPs was sent to the School of Physics at USM for phase identification of crystalline material and unit cell dimension measurement using the XRD D8 (Bruker, USA) operated at a voltage of $30 \mathrm{kV}$ and a current of $30 \mathrm{~mA}$ with $\mathrm{CuKa}$ radiation in a $\theta-2 \theta$ configuration. Further analyses were performed to determine the average size of the AgNPs using Dp Calculator software from http://mahendrakoppolu.blogspot.com/2013/07/onlinecrystallite-size-calculator.html

\section{Transmission electron microscope (TEM) analysis}

Size and shape of synthesized C. roseus-AgNPs were observed using a TEM CM12 (Phillips, USA) at the School of Biological Sciences, USM. The $C$. roseus-AgNPs were transferred into a new vial using a spatula. A 
Citation: Ghozali SZ, Vuanghao L, Ahmad NH (2015) Biosynthesis and Characterization of Silver Nanoparticles using Catharanthus roseus Leaf Extract and its Proliferative Effects on Cancer Cell Lines. J Nanomed Nanotechnol 6: 305. doi:10.4172/2157-7439.1000305

Page 3 of 6

suspension was made by adding $95 \%$ alcohol, followed by $15 \mathrm{~min}$ ultrasonication in an ultrasonic water bath (Elmasonic S 80H, Elma, Singen (Hohentwiel), Germany). A drop of suspension was loaded onto a carbon-coated grid and allowed to evaporate before viewing.

\section{Preparation of cell lines for cell proliferation assay}

HT-29 and Jurkat cell lines were purchased from American Type Culture Collection (ATCC, USA). The cells were cultured and maintained in $10 \%$ fetal calf serum (v/v) (Gibco, USA), $1 \%$ penicillinstreptomycin (v/v) (Gibco, USA), and 1\% L-glutamine (v/v) (Gibco). The cells were harvested in the log phase of growth and centrifuged at $1200 \mathrm{rpm}$ for $10 \mathrm{~min}$. The pellet was resuspended in RPMI complete growth medium at a concentration of $4 \times 10^{5}$ cells $/ \mathrm{ml}$ for Jurkat cells and $1 \times 10^{5}$ cells $/ \mathrm{ml}$ for HT-29 cells.

\section{Proliferation assay}

Cell proliferation was assessed using the MTS [3-(4,5-dimethylthiazol-2-yl)-5-(3-carbonxymethoxyphenyl)-2-(4sulfophenyl)-2H-tetrazolium/phenazine metho sulfate] kit (Promega, USA) following the manufacturer's protocol. Cells were treated with either C. roseus-AgNPs or C. roseus aqueous extract at concentrations of $3.91,7.82,15.63,31.25,62.5,125,250,500$, and $1000 \mu \mathrm{g} / \mathrm{ml}$ in $96-w e l l s$ plates. The plates were incubated for 24,48 , and $72 \mathrm{~h}$. Untreated cells were used as the control, and vinblastine (VB) was used as the positive control. Each sample type was run in triplicate. Following the particular incubation time, the culture cells in each well were added with a mixture of MTS/PMS with a ratio of 20:1. The plates were read at $490 \mathrm{~nm}$ using an ELISA reader (Bio Tek, USA). The half maximal inhibitory concentration $\left(\mathrm{IC}_{50}\right)$ values were determined from the graph to obtain the sample concentration that caused $50 \%$ cell death. Cell viability (\%) was calculated as follows:

Cell viability (\%)=Mean OD of treated cells $\mathrm{x} 100$

Mean OD of untreated (control) cells

Where OD is optical density.

\section{Statistical analysis}

Data were expressed as mean \pm SEM. Statistical analysis was performed using IBM SPSS Statistics Version 20.0. Control and treated samples were compared using one way analysis of variance. Differences at $p>0.05$ were considered to be statistically significant.

\section{Results and Discussion}

\section{UV-Vis spectra analysis of silver nanoparticles}

Figure 1 shows the color changes at $24 \mathrm{~h}$ of incubation after the addition of $10 \%(\mathrm{w} / \mathrm{v})$ and $20 \%(\mathrm{w} / \mathrm{v})$ C. roseus aqueous extract to 1 $\mathrm{mM}$ and $5 \mathrm{mM}$ of $\mathrm{AgNO}_{3}$ solution. Neither concentration of $C$. roseus
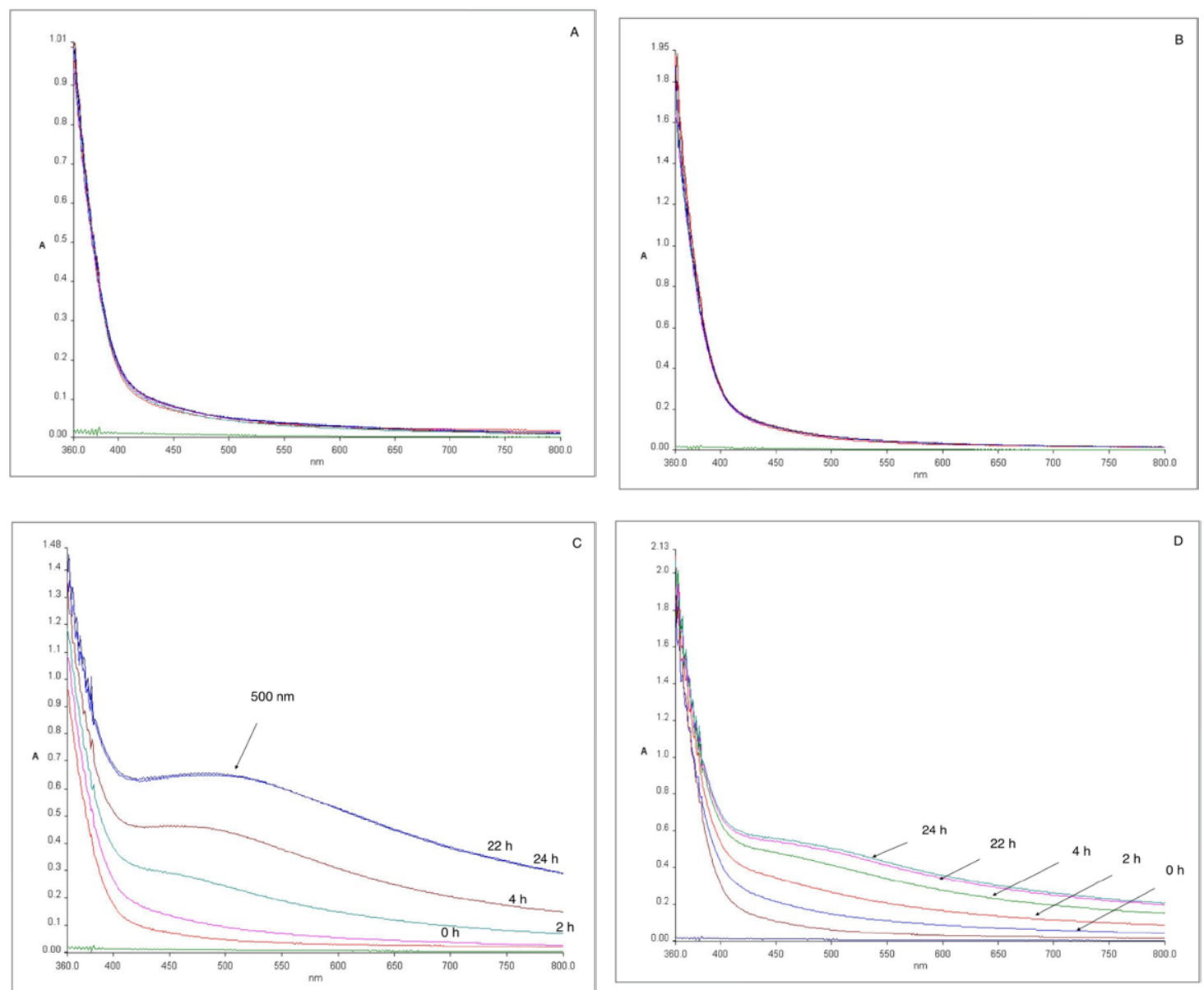

Figure 2: UV-Vis absorption spectra of (A) $1 \mathrm{mM} \mathrm{AgNO}_{3}+10 \%$ C. roseus leaf extract, (B) $1 \mathrm{mM}+20 \%$, (C) $5 \mathrm{mM}+10 \%$, and (D) $5 \mathrm{mM}+20 \%$ prepared using Method 1 , at different time intervals. 
Citation: Ghozali SZ, Vuanghao L, Ahmad NH (2015) Biosynthesis and Characterization of Silver Nanoparticles using Catharanthus roseus Leaf Extract and its Proliferative Effects on Cancer Cell Lines. J Nanomed Nanotechnol 6: 305. doi:10.4172/2157-7439.1000305

Page 4 of 6

aqueous extract with $1 \mathrm{mM} \mathrm{AgNO}$ solution resulted in a color change. In contrast, both concentrations of $C$. roseus aqueous extract in $5 \mathrm{mM}$ $\mathrm{AgNO}_{3}$ solution showed a color change from light yellow to browngray after $24 \mathrm{~h}$ of incubation due to excitation of surface plasmon resonance (SPR). This change indicated the formation of AgNPs [17].

UV-Vis spectroscopy was used to confirm the formation and stability of AgNPs. Figure 2 shows the absorption spectra of the four different solutions prepared using method 1 . No distinct peaks were observed for the solutions with concentrations of $10 \%(\mathrm{w} / \mathrm{v})$ and $20 \%(\mathrm{w} / \mathrm{v})$ C. roseus aqueous extract in $1 \mathrm{mM} \mathrm{AgNO}_{3}$ solution at any time point. In contrast, broad peaks were observed for the solutions with concentrations of $10 \%(\mathrm{w} / \mathrm{v})$ and $20 \%(\mathrm{w} / \mathrm{v})$ C. roseus aqueous extract in $5 \mathrm{mM} \mathrm{AgNO}$ solution. The highest absorbance peaks (at approximately $500 \mathrm{~nm}$ ) at $24 \mathrm{~h}$ were observed for the $10 \%(\mathrm{w} / \mathrm{v}) C$. roseus aqueous extract in $5 \mathrm{mM} \mathrm{AgNO}$ solution, indicating the formation of AgNPs [17]. Various reports have established that the resonance peak of AgNPs appears around this region. Sileikaite et al. [19] reported that the absorption band of AgNPs is in the range of 350 to $550 \mathrm{~nm}$. Figure 3 shows the absorption spectra of AgNP solutions prepared using method 2 (i.e., boiling at $100^{\circ} \mathrm{C}$ for $5 \mathrm{~min}$ ). None of the AgNP solutions prepared this way showed any visible absorbance peak, which suggests that AgNPs were not produced.

\section{Size and shape characterization of AgNPs Using TEM}

According to Pasupuleti [15], the applications for AgNPs are highly dependent on the chemical composition, shape, size, and mono dispersity of the particles. These characteristics of the AgNPs synthesized using C. roseus aqueous extract were evaluated by TEM. AgNPs harvested from the $10 \%(\mathrm{w} / \mathrm{v})$ C. roseus aqueous extract in 5 $\mathrm{mM} \mathrm{AgNO}$ solution created using methods 1 and 2 were compared. Figure 4 shows that method 1 produced particle sizes ranging from 20 to $50 \mathrm{~nm}$ (average diameter, $30 \mathrm{~nm}$ ). Gopinath [1] also successfully synthesized AgNPs with a diameter range of 20 to $50 \mathrm{~nm}$. In contrast, Figure 5 shows that method 2 produced a greater range of particle sizes, which ranged from 10 to $250 \mathrm{~nm}$. Basanagowda and Ashok [10] also successfully synthesized AgNPs using the boiling method to generate Duranta repens leaf extract, but the particle size was only 30 to $80 \mathrm{~nm}$. This explains the absence of a plasmon resonance band in UV-Vis spectroscopy analysis of the AgNP solution prepared by the boiling method in recent study. However, both methods produced spherical shaped AgNPs.

\section{XRD analysis}

$\mathrm{XRD}$ analysis was conducted to determine the crystal structure of AgNPs. Figure 6 shows the XRD diffraction pattern of AgNPs. Four distinct diffraction peaks at $2 \theta$ with values of $38.12^{\circ}, 44.31^{\circ}$, $64.45^{\circ}$, and $77.41^{\circ}$ were indexed with the planes $111,200,220$, and 311 , respectively, which indicate that the particles were face-centered cubic silver. Further analysis was performed to determine the size of the AgNPs using Dp Calculator software. The average particle size was $29.27 \mathrm{~nm}$, which matched the result obtained by TEM $(30 \mathrm{~nm})$.
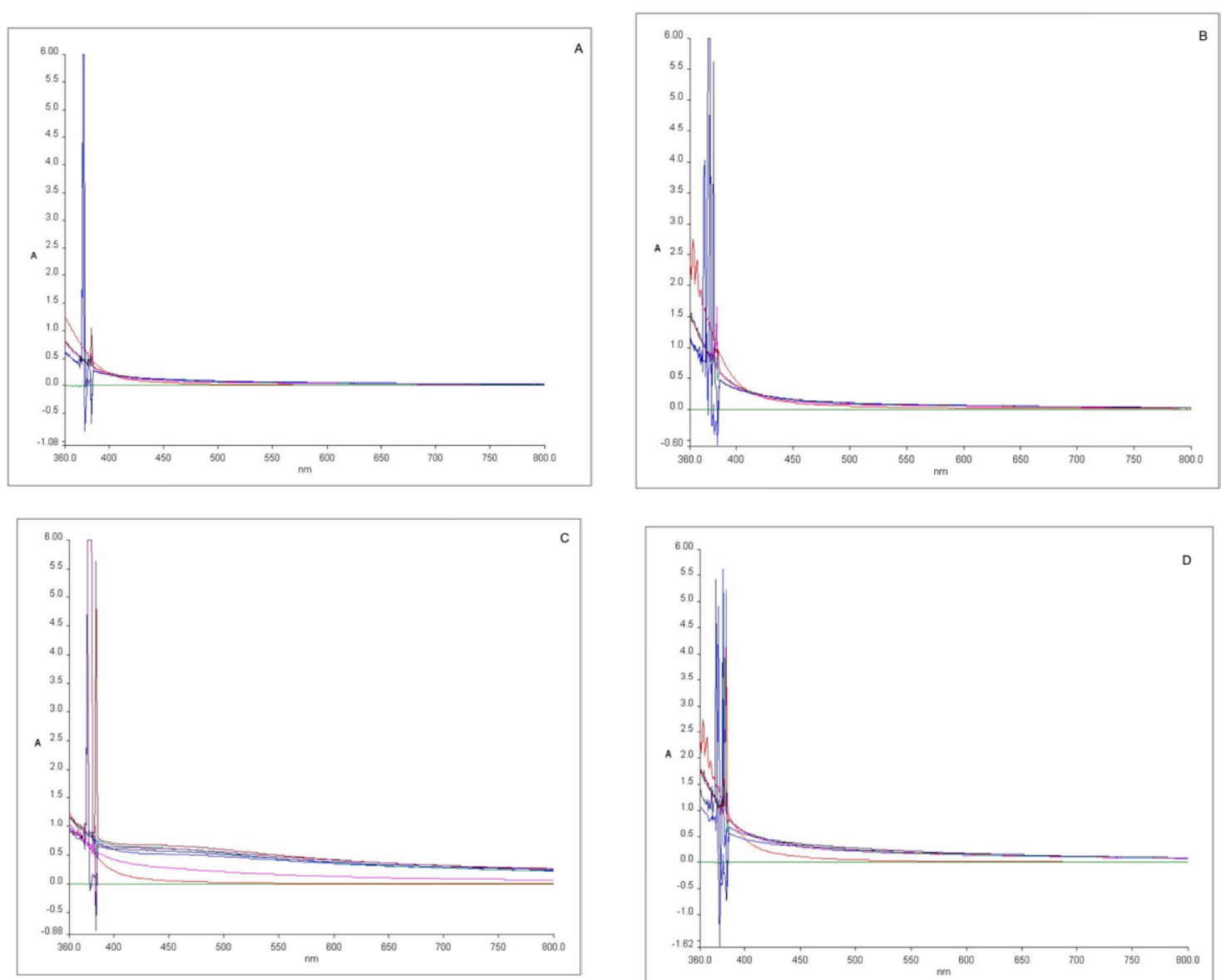

Figure 3: UV-Vis absorption spectra of (A) $1 \mathrm{mM} \mathrm{AgNO}_{3}+10 \%$ C. roseus leaf extract, (B) $1 \mathrm{mM}+20 \%$, (C) $5 \mathrm{mM}+10 \%$, and (D) $5 \mathrm{mM}+20 \%$ prepared using Method 2, at different time intervals. 
Citation: Ghozali SZ, Vuanghao L, Ahmad NH (2015) Biosynthesis and Characterization of Silver Nanoparticles using Catharanthus roseus Leaf Extract and its Proliferative Effects on Cancer Cell Lines. J Nanomed Nanotechnol 6: 305. doi:10.4172/2157-7439.1000305

Page 5 of 6
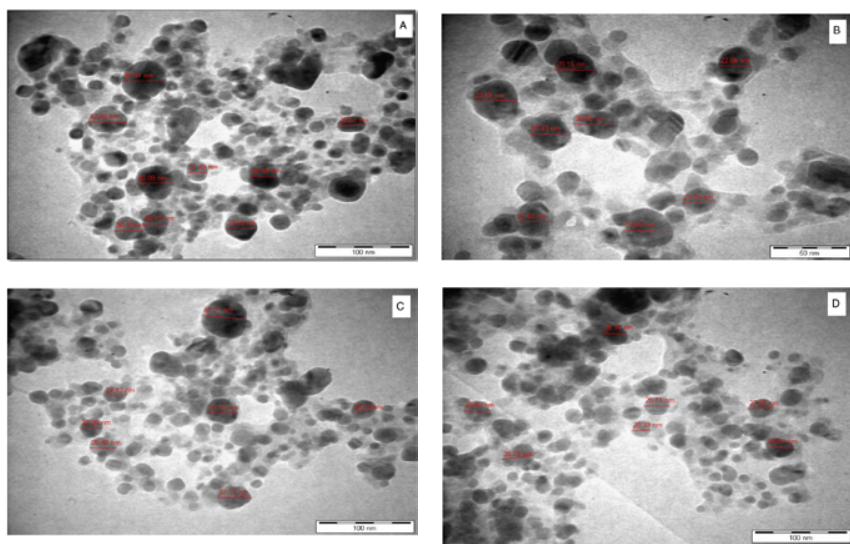

Figure 4: TEM images of AgNPs synthesized using method 1 taken from different angles.
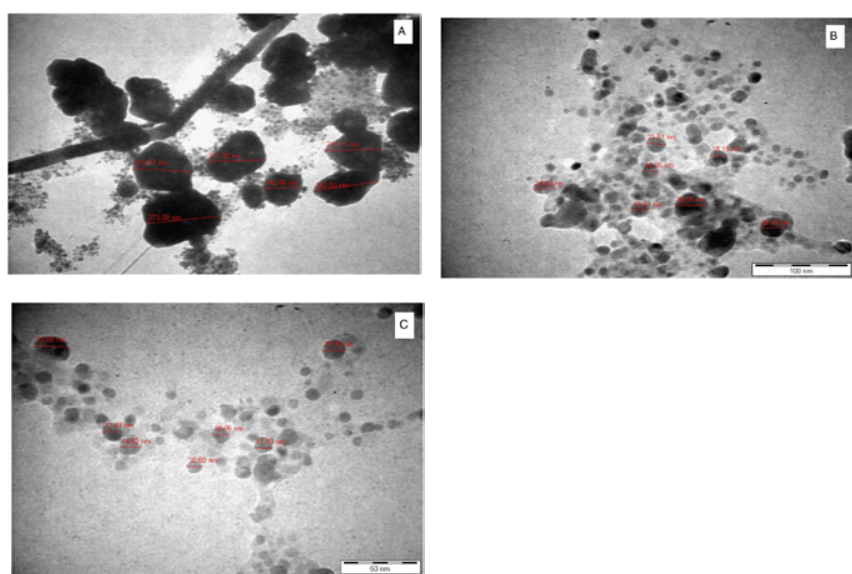

Figure 5: TEM images of AgNPs synthesized using method 2 taken from different angles.

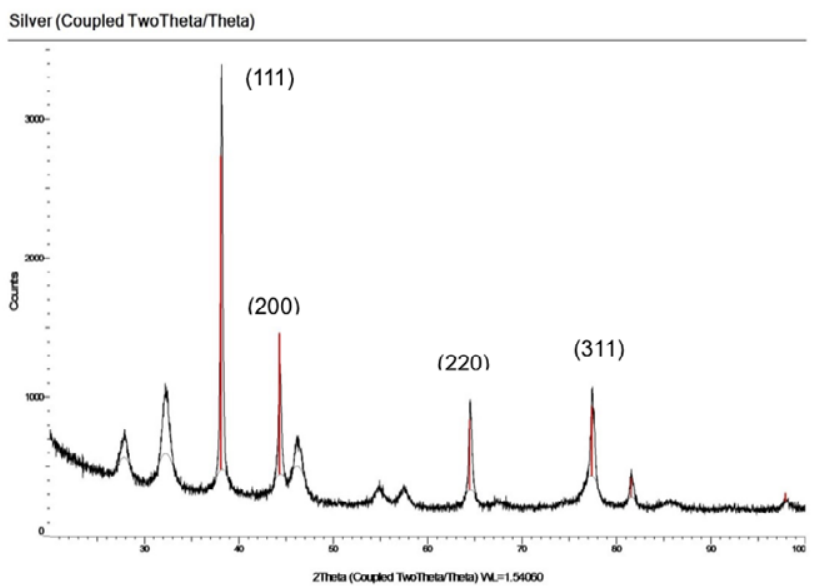

Figure 6: XRD patterns of AgNPs synthesized using C. roseus leaf extract.

\section{Proliferative assay}

Proliferative assay was carried out to compare the effects of AgNPs on adherent (HT-29) and suspension (Jurkat) cancer cells. Figure 7a compares the effect of synthesized C. roseus-AgNP treatment on Jurkat and HT-29 cells. The $\mathrm{IC}_{50}$ values of treated Jurkat cells were 13.68 , 27.35, and $46.88 \mu \mathrm{g} / \mathrm{ml}$ of AgNPs at 24, 48, and $72 \mathrm{~h}$, respectively. Significant inhibition $(p>0.05)$ of cell proliferation was observed, especially at AgNP concentrations ranging from 62.5 to $1000 \mu \mathrm{g} / \mathrm{ml}$ at all incubation times, with the percentage of viable cells remaining $<40 \%$. Whereas, C. roseus-AgNP inhibited $50 \%$ of the HT-29 cells at concentration of $23.44,39.06$ and $46.88 \mu \mathrm{g} / \mathrm{ml}$ at 24,48 , and $72 \mathrm{~h}$, respectively. Significant inhibition $(p>0.05)$ of cell proliferation also was observed at $31.25 \mu \mathrm{g} / \mathrm{ml}$ at all incubation times, but it increased in a time-dependent manner. Interestingly, cell proliferation was induced at $3.91,7.82$, and $15.63 \mu \mathrm{g} / \mathrm{ml}$ at 48 and $72 \mathrm{~h}$. These data show that Jurkat cells were more sensitive than HT29 cells to the toxicity of $C$. roseus-AgNPs.

Figure $7 \mathrm{~b}$ compares the effect of $C$. roseus aqueous extract on Jurkat and HT-29 cells. The IC C $_{50}$ values for Jurkat cells were 62.5 and $312.5 \mu \mathrm{g} / \mathrm{ml}$ at 48 and $72 \mathrm{~h}$, respectively. Significant differences $(p>0.05)$ with respect to the untreated group were observed at all concentrations. Inhibition of cell proliferation was time dependent at extract concentrations of $62.5,250,500$, and $1000 \mu \mathrm{g} / \mathrm{ml}$. The highest concentration of $C$. roseus aqueous extract tested $(1000 \mu \mathrm{g} / \mathrm{ml})$ produced the highest rate of cell inhibition. In contrast, no $\mathrm{IC}_{50}$ values were obtained for HT-29 cells, suggesting that $>50 \%$ of HT- 29 cells remained viable in response to the extract treatment throughout the experiment. However, significant differences $(p>0.05)$ in cell inhibition with respect to the untreated group were observed at concentrations of 250 and $500 \mu \mathrm{g} / \mathrm{ml}$ at all incubation times. Inhibition of cell proliferation was also observed in response to $3.91,7.82,15.63,31.25,62.5,125$, and $1000 \mu \mathrm{g} / \mathrm{ml}$ of the extract, but only at 48 and $72 \mathrm{~h}$. In contrast, a significant $(p>0.05)$ induction of cell proliferation was observed at concentrations of 3.91 , $7.82,15.63,31.25$, and $250 \mu \mathrm{g} / \mathrm{ml}$ at $24 \mathrm{~h}$. Thus, these data also suggest

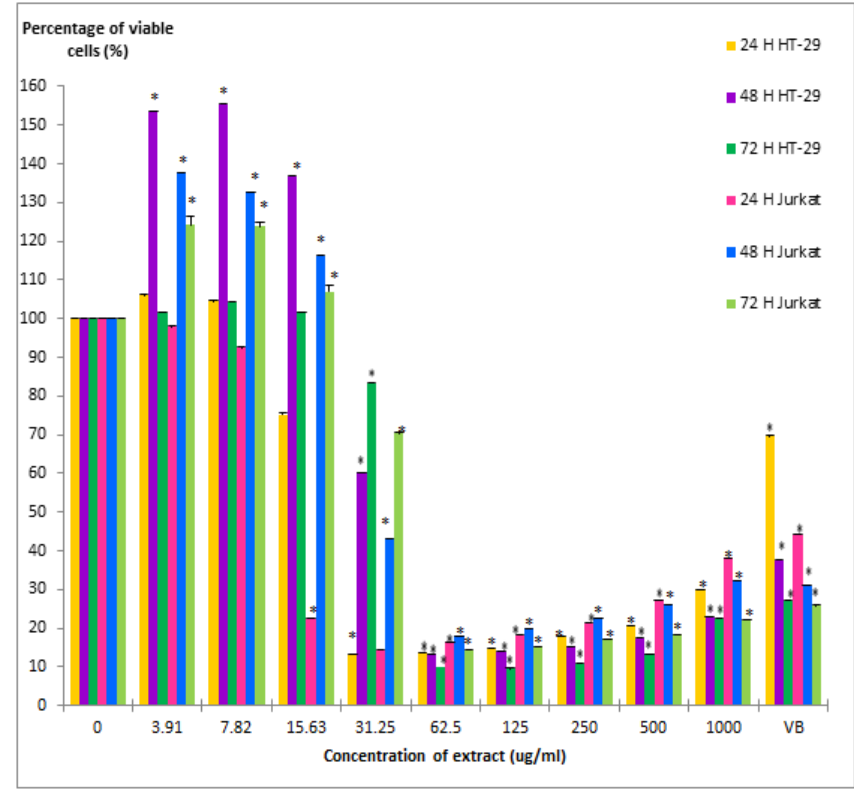

Figure 7a: Comparison of the growth inhibition effect of synthesized C. roseusAgNPs on Jurkat and HT-29 cells. Untreated cells were used as the control and VB was used as the positive control. The values represent means \pm SEM of triplicate measurements. *indicates a significant difference $(p>0.05)$ with respect to the untreated group. 
Citation: Ghozali SZ, Vuanghao L, Ahmad NH (2015) Biosynthesis and Characterization of Silver Nanoparticles using Catharanthus roseus Leaf Extract and its Proliferative Effects on Cancer Cell Lines. J Nanomed Nanotechnol 6: 305. doi:10.4172/2157-7439.1000305

Page 6 of 6

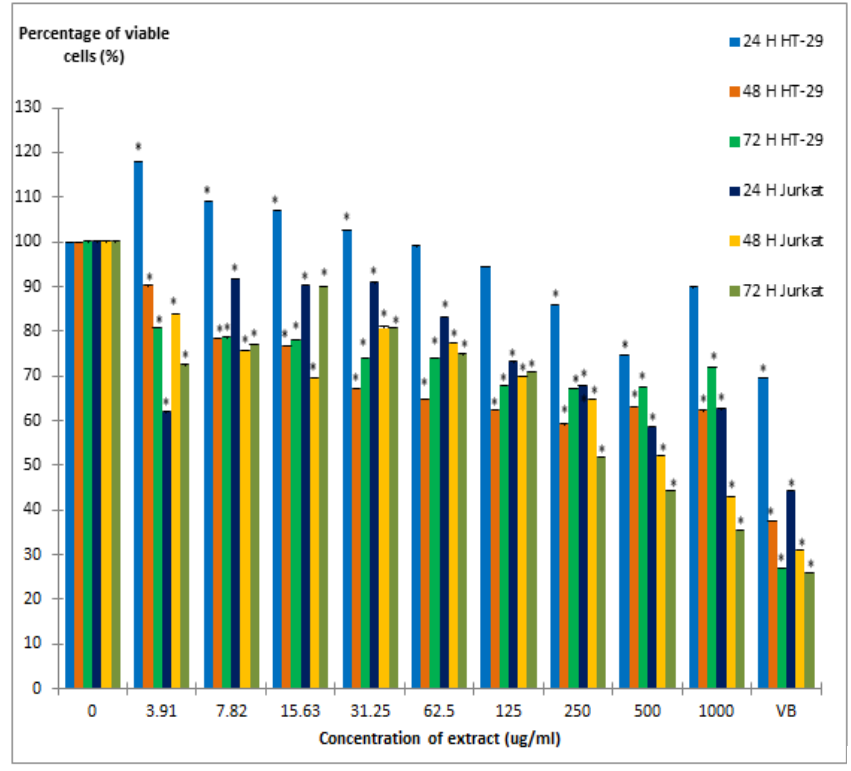

Figure 7b: Comparison of the growth inhibition effect of $C$. roseus aqueous extract on Jurkat and HT-29 cells. Untreated cells were used as the control and VB was used as the positive control. The values represent means \pm SEM of triplicate measurements. *indicates a significant difference $(p>0.05)$ with respect to the untreated group.

that Jurkat cells were more sensitive than HT-29 cells to the toxicity of C. roseus aqueous extract.

In conclusion, the synthesized $C$. roseus-AgNPs shows higher toxicity effects compared to $C$. roseus aqueous extract on both cell types. However, both treatments are more effective in inhibiting Jurkat cells compared to HT-29 cells.

\section{Conclusion}

Herein, we demonstrated that the extract of the C. roseus leaf is capable of producing AgNPs extracellularly by rapid reduction of silver ions. This technique may prove useful for developing large-scale commercial production of value-added products for biomedical or nanotechnology-based industries. This green synthesis method offers a rapid and reliable way to synthesize AgNPs. Further studies should be conducted to better understand the mechanisms by which these AgNPs function as an anti-cancer therapy. These AgNPs should also be tested on normal cells, as a good anti-cancer compound should be selectively cytotoxic to cancer cells and have minimal cytotoxic activity or be nontoxic to normal cells.

\section{Acknowledgment}

The authors are grateful to the AMDI Student Research Fund and Science Fund Grant, under the Ministry of Science, Technology and Innovation (MOSTI) with grant number 305/CIPPT/613234. Thank you to Prof. Ishak Mat, AMDI lecturer, for the cell lines provided.

\section{Disclosure}

The authors report no conflict of interest in this work.

\section{References}

1. Gopinath K, Gowri S, Arumugam A (2013) Phytosynthesis of silver nanoparticles using Pterocarpus santalinus leaf extract and their antibacterial properties. Journal of Nanostructure in Chemistry 3

2. Sriram MI, Kanth SB, Kalishwaralal K, Gurunathan S (2010) Antitumor activity of silver nanoparticles in Dalton's lymphoma ascites tumor model. Int $J$ Nanomedicine 5: 753-762.

3. Mukunthan KS, Elumalai EK, Patel TN, Murty VR (2011) Catharanthus roseus: a natural source for the synthesis of silver nanoparticles. Asian Pac J Trop Biomed 1: 270-274.

4. Kotakadi VS, Rao YS, Gaddam SA, Prasad TN, Reddy AV, et al. (2013) Simple and rapid biosynthesis of stable silver nanoparticles using dried leaves of Catharanthus roseus Linn G Donn and its anti microbial activity. Colloids and Surface Biointerfaces 105: 194-198.

5. Mubayi A, Chatterji S, Rai PK, Watal G (2012) Evidence based green synthesis of nanoparticles. Advance Materials Letters 3: 519-525.

6. Bhattacharya DI, Gupta RK (2005) Nanotechnology and potential of microorganisms. See comment in PubMed Commons below Crit Rev Biotechnol 25: 199-204.

7. Mohanpuria P, Rana NK, Yadav SK (2007) Biosynthesis of nanoparticles: technological concepts and future applications. Journal of Nanoparticles Research 10:507-517.

8. Saifuddin N, Wong CW, Yasumira AAN (2009) Rapid biosynthesis of silver nanoparticles using culture supernatant of bacteria with microwave irradiation. E-Journal of Chemistry 6: 61-70.

9. Mukherjee P, Roy M, Mandal BP, Dey GK, Mukherjee PK, et al. (2008) Green synthesis of highly stabilized nanocrystalline silver particles by a nonpathogenic and agriculturally important fungus $T$. asperellum. Nanotechnology 19: 075103

10. Basanagowda MP, Ashok AH (2013) Green synthesis of silver nanoparticles by Duranta repens leaves and their antimicrobial efficacy. Nano Trends: A Journal of Nanotechnology and Its Application 14: 13-18.

11. Huang J, Li Q, Sun D, Lu Y, Su Y, et al. (2007) Biosynthesis of silver and gold nanoparticles by novel sundried Cinnamomum camphora leaf. Nanotechnology 18: 105104.

12. Awwad AM, Salem NM, Abdeen AO (2012) Biosynthesis of silver nanoparticles using Olea europaea leaves extract and its antibacterial activity. Nanoscience and Nanotechnology 2: 164-170.

13. Awwad AM, Salem NM, Abdeen AO (2013) Biosynthesis of silver nanoparticles using Loquat leaf extract and its antibacterial activity. Advance Materials Letters 4: 338-342.

14. Vivek R, Thangam R, Muthuchelian K, Gunasekaran P, Kaveri K, et al. (2012) Green biosynthesis of silver nanoparticles from Annona squamosa leaf extract and its in vitro cytotoxic effect on MCF 7 cells. Process Biochemistry 47: 24052410.

15. Pasupuleti VR, Prasad TNVKV, Shiekh RA, Balam SK, Narasimhulu G, et al (2013) Biogenic silver nanoparticles using Rhinacanthus nasutus leaf extract: synthesis, spectral analysis, and antimicrobial studies. International Journal of Nanomedicine 8: 3355-3364.

16. Malabadi RB, Chalannavar RK, Meti NT, Mulgund GS, Nataraja K, et al. (2012) Synthesis of antimicrobial silver nanoparticles by callus cultures in vitro derived plants of Catharanthus roseus. Research in Pharmacy 2: 18-31.

17. Ponarulselvam S, Panneerselvam C, Murugan K, Aarthi N, Kalimuthu K, et al. (2012) Synthesis of silver nanoparticles using leaves of Catharanthus roseus Linn G Don and their antiplasmodial activities. Asian Pacific Journal of Tropical Biomedicine 2: 574-580.

18. Ahmad NH, Rahim RA, Mat I (2010) Catharanthus roseus aqueous extract is cytotoxic Jurkat leukemic T-cells but induces the proliferation of normal peripheral blood mononuclear cells. Tropical Life Sciences Research 21: 101-113.

19. Sileikaite A, Prosycevas I, Puiso J, Juraitis A, Guobiene A (2006) Analysis of silver nanoparticles produced by chemical reduction of silver salt solution. Materials Science. 